\title{
Record of Arbuscular Mycorrhizal Fungi (AMF) in Pippali Plant under the Agro Ecological Conditions of Jorhat District, Assam, India
}

\author{
M. Deori and Pranab Dutta*
}

Department of Plant Pathology, Assam Agricultural University, Jorhat-785013, Assam, India

*Corresponding author

Keywords

A.M fungi, Assam,

Pippali, Root and soil colonization, Spore density

Article Info

Accepted:

10 December 2018

Available Online:

10 January 2019

\section{A B S T R A C T}

Arbuscular mycorrhizal status of Pippali a medicinal plant species in the Jorhat district of Assam, India were surveyed during 2018. Percent colonization, spore density and diversity of arbuscular mycorrhizal fungi associated with the rhizospheric soil and roots of pippali growing wild as well as under cultivated conditions were investigated. It was found that $100 \%$ of the surveyed sample was of mycorrhizal infestation. The spore colonization per cent of AMF ranged from 30.80 to $66.50 \%$ spores per $100 \mathrm{~g}$ of soil. The maximum spore population (185.80 spores/ $100 \mathrm{gm}$ of soil) was obtained on soil samples collected from Gibbon wild life sanctuary. This was followed by soil sample collected from Katoni par Soil sample collected from Upper deori gaon, Nakachari gaon, and Nagajanka showed spore population of 168.80 to 154.65 spores $/ 100 \mathrm{ml}$ of soil. Result showed that root colonization by abuscular mycorrhizal fungi both in roots and soil of Pippali. But, percentage of root and soil colonization varies according to location. Variation in the spore density and percent colonization among different sampling sites could be attributed to host specificity, adaphic and climatic conditions. After comparing with synoptic key the genus of the mychorrhiza was identified tentatively as Glomus spp.

\section{Introduction}

Agriculture is the dominant land use pattern in the state Assam. It account for about 54.11 percent of the total geographical area of the state. Including persons dependent on plantation, more than 80 percent of total populations of Assam is dependent on agriculture. Agriculture plays an important role in revenue earning in Assam economy. The Assam experiences a plenty of rainfall and possess a fertile land which is extremely advantageous for cropping. Among the different districts of Assam, by understanding the existing agro ecological conditions of the study area is seen suitable for a growing of Pippali plant for the study and record of arbuscular mycorrhizal fungi in this particular plant.

Jorhat district is located between $26^{\circ} 20^{\prime} \mathrm{N}$ and $27^{\circ} 15^{\prime} \mathrm{N}$ latitudes and between $94^{\circ} 00^{\prime} \mathrm{E}$ longitudes. On the north, it is bounded by Lakhimpur, east by Sivasagar, west by Golaghat districts of Assam and on the south by Nagaland state. Regarding the soils, basically alluvium in nature and climate belongs to four main types, viz., humid 
continental severe winter, moist in all seasons and short summer, sub tropical monsoons, mild and dry winter, warm and humid summer, sub tropical monsoon, mild and dry winter and sub tropical monsoon with very heavy rain.

A large number of microorganisms are associated with the roots of plant in their natural habitat. Among them mycorrhiza plays a highly evolved association with the root system. Mutualistic symbiosis is one of the most abundant symbiotic activities in ecosystems. Arbuscular mycorrhizae are symbiotic associations formed between fungi, which belong to the phylum Glomeromycota (Schubler et al., 2001) and the root system of many plant species. Arbuscular mycorrhizal fungi (AMF) are known to play an important role in improvement of plant nutrition and growth of several ornamentals and vegetable crops (Rouphael et al., 2010; Koltai 2010). Amongst the microorganisms, AMF are able to solubilize insoluble phosphates and improve plant $\mathrm{P}$ nutrition (Zarei et al., 2006). Several studies have been performed on changing secondary compound patterns of medicinal plant symbiosis with mycorrhizal fungi such as terpenoids (Akiyama and Hayashi 2002), phenols (Zhu and Yao 2004), phenylpropanoids (Weiss et al., 1997), glucosinolates (Vierheilig et al., 2000), carotenoids (Maier et al., 1995) and flavonoids (Larose et al., 2002).

Pippali (Piper longum), sometimes called Indian long piper (Pipli) is a flowering vine in the family Piperacea, cultivated for its fruit, which is usually dried and used as a spice and seasoning. The plant itself, is a native of India. The fruit contain the alkaloid piperine, which contributes to their pungency. Long piper is a climber, of South Asian origin (Deccan peninsula). The word piper itself is derived from the Sanskrit word for long piper, pippali. It is a slender, aromatic, climber with perennial woody roots, creeping and jointed stems, and fleshy fruits embedded in spikes. Leaves are numerous, 6.3 to $9.0 \mathrm{~cm}$, broadly ovate or oblong oval, dark green and shining above, pale and dull beneath. The older leaves are dentate, dark in color and heart shaped. The younger leaf is ovate in shape and contains 5 veins on them. Flowers are monoceous and male and female flowers are borne on different plants. The plant flowers in rains and fruits in early winters.

Pippali is certainly one of the most widely used of all Ayurvedic herbs. It is one of the best herbs for enhancing digestion, assimilation and metabolism of the foods we eat. It is also highly prized for its ability to enhance assimilation and potency of herbs in a synergistic formula (this is called the Yogavahi effect).

The present study was based on record of arbuscular mycorrhizal fungi (AMF) in Pippali plant under the agro ecological conditions of Jorhat district, Assam.

\section{Materials and Methods}

\section{Collection of Rhizosphere soil sample and root sample of Pippali}

Field survey was carried out in order to collect the root and rhizospheric soil sample of Pippali Plant from different blocks of Jorhat district, Assam (Fig. 1). Rhzospheric soils at a depth of $0-30 \mathrm{~cm}$ from 10 different locations were collected in sterile polyethylene bags (Table 1). Approximately 100gm of rhizospheric soil was collected and were air dried and stored at $4^{\circ} \mathrm{C}$ for processing. For the collection of root sample, feeder roots were collected immediately after digging the plant. For the maintenance and preservation of roots, collected sample were washed under running tap water and rootlets were selected and cut into small pieces and fixed in acetic acid solution. 
Study the root colonization of arbuscular mycorhizal fungi

To study the root colonization of Arbuscular myccorhizal fungi in the roots of Pippali the standard procedure of Philip and Haymann, (1970) was followed. Per location few roots were selected randomly and sections were made and placed in glass slides and observed 10 section from each slide for 3 slides under microscope for root colonization. Number of root colonized were counted and percentage of root colonization was calculated by following formula,

Root colonization percentage $=\frac{\text { no. of infected root section }}{\text { no. of total root section }} \times 100$

\section{Isolation of AMF spores from soil sample}

Isolation of AMF spores from soil sample was done by following the Wet Seiving and decanting methods of Gerdemann and Nicolson, (1963). Spore population was then expressed in terms of number of spores per $100 \mathrm{gm}$ of dry soil.

\section{Characterization of arbuscular mycorhizal fungi}

The AMF isolated from Pippali plant as loose clusters of spores or as sporocarps and chlamydospores were characterized on the basis of spore morphology (size,shape,colour) wall character and hyphae attachment up to generic or if possible to species level using synoptic key of Trappe (1982) and INVAM manual of Schenck and Perez (1988).

\section{Results and Discussion}

\section{Study of root colonization of AMF}

Colonization of Pippali plant by AMF was ascertained by the presence of fungal structure in root segments. There was distinct variation in per cent AMF colonization of root samples collected from Pippali growing pockets from different locations of Jorhat. The highest AMF colonization (66.50\%) was found in Gibbon wild life sanctuary followed by Katonipar (64.6\%). This was followed by Upper Deorigaon, Karanga, Experimental garden, Department of Horticulture (AAU) and Nagajanka with spore colonization of $6.42 \%$, $55.5 \%, 54.5 \%$ and $52.7 \%$ respectively. Lowest root colonization percentage was found in Lahdoigarh (30.80\%) (Table 2).

\section{Isolation of AMF spores from soil sample}

It was observed that AMF propagules in different soil samples ranged between 110.00 to 185.80 per $100 \mathrm{~g}$ of soil sample. The highest spore load of 185 AMF spores per $100 \mathrm{~g}$ soil samples in Pippali rhizosphere was observed in soil sample collected from Gibbon Wild Life sanctuary followed by Katonipar (176.00 spores per $100 \mathrm{~g}$ of soil sample) (Table 3). Soil sample collected from Upper Deorigaon, Nakachari, and Nagajanka showed spore population of 168.80 to 154.65 spores $/ 100 \mathrm{ml}$ of soil. The soil of Lahdoigarh was found registered lowest (110.55/g soil).

\section{Identification of arbuscular mycorrhizal fungi}

AMF spores isolated from Pippali from 10 different locations of Jorhat belonging to the genera Glomus were identified up to generic level on the basis of morphological characters using standard taxonomic key (Trappe, 1982; Schenck and Perez,1988).

Microscopic study showed that spore borne singly, round to globose shaped with smooth double layered wall or fused, spore measuring 60-75 X 90-110 $\mu \mathrm{m}$ in size, spore colour was yellow brown to dark brown, spore wall cavity absent (Plate 2). After comparing with synoptic key the genus of the mychorrhiza 
was identified tentatively as Glomus spp as per the available standard key (Schenck and Perez, 1990). Studies on the distribution of AMF fungi in different locations revealed the predominance occurrence of AMF spores belonging to genus Glomus sp. which were dominant in distribution and abundance.

The distribution pattern of AMF in 10 different locations of 4 blocks of Jorhat districts of Assam revealed prevalence of spores of genera of AMF viz., Glomusspp.Glomusspp were the common AMF fungi in the majority of Pippali soils.
Glomusspp are known to be the most common AMF throughout the world (Gerdeman and Trappe, 1974., Blaszkowski, 1989; Talukdar, 1993). The frequent detection of spores of Glomus spp. in the soils of selected Pippali growing of Jorhat district, Assam in the present investigation therefore supports the earlier findings. The occurrence of the five genera of AMF fungi were also reported earlier from Assam in tea and other crops by various workers (Anonymous, 1982; Hazarika, 1992; Baruah, 1994; Chaudhury,1998; Das and Barthakur, 1999).

Table.1 Details of locations surveyed for collection of soil and plant sampl Pippali from different blocks of Jorhat district

\begin{tabular}{|c|c|c|c|c|}
\hline SI no. & Location & GPS data & $\begin{array}{l}\text { Date of } \\
\text { survey }\end{array}$ & $\begin{array}{l}\text { Collection } \\
\text { made }\end{array}$ \\
\hline 1 & $\begin{array}{l}\text { Experimental garden, Department } \\
\text { of Horticulture (AAU) }\end{array}$ & $\begin{array}{l}26.724^{\circ} \mathrm{N} \text { and } \\
94.195^{\circ} \mathrm{E}\end{array}$ & $02 / 12 / 17$ & $\begin{array}{l}\text { Plant and soil } \\
\text { sample }\end{array}$ \\
\hline 2 & $\begin{array}{l}\text { Gibbon Wild Life Sanctuary } \\
\text { (GWS) }\end{array}$ & $\begin{array}{l}26.716^{\circ} \mathrm{N} \text { and } \\
94.383^{\circ} \mathrm{E}\end{array}$ & $02 / 12 / 17$ & -do- \\
\hline 3 & Nakachari (NAK) & $\begin{array}{l}26.702^{\circ} \mathrm{N} \text { and } \\
94.450^{\circ} \mathrm{E}\end{array}$ & $02 / 12 / 17$ & -do- \\
\hline 4 & Nagajanka (NAG) & $\begin{array}{l}26.718^{\circ} \mathrm{N} \text { and } \\
94.470^{\circ} \mathrm{E}\end{array}$ & $02 / 12 / 17$ & - do- \\
\hline 5 & Karanga (KAR) & $\begin{array}{l}26.695^{\circ} \mathrm{N} \text { and } \\
94.238^{\circ} \mathrm{E}\end{array}$ & $03 / 12 / 17$ & -do- \\
\hline 6 & Upper DeoriGaon (UDG) & $\begin{array}{l}26.829^{\circ} \mathrm{N} \text { and } \\
94.119^{\circ} \mathrm{E}\end{array}$ & $05 / 12 / 17$ & -do- \\
\hline 7 & NamdeoriGaon (NDG) & $\begin{array}{l}26.827^{\circ} \mathrm{N} \text { and } \\
94.086^{\circ} \mathrm{E}\end{array}$ & $05 / 12 / 17$ & -do- \\
\hline 8 & Katoni Par (KP) & $\begin{array}{l}26.820^{\circ} \mathrm{N} \text { and } \\
94.074^{\circ} \mathrm{E}\end{array}$ & $10 / 01 / 18$ & -do- \\
\hline 9 & PukhuriporiaGaon (PPG) & $\begin{array}{l}26.800^{\circ} \mathrm{N} \text { and } \\
94.070^{\circ} \mathrm{E}\end{array}$ & $10 / 01 / 18$ & -do- \\
\hline 10 & Lahdoigarh (LAH) & $\begin{array}{c}26.785^{\circ} \mathrm{N} \text { and } \\
94.324^{\circ} \mathrm{E}\end{array}$ & $25 / 01 / 18$ & -do- \\
\hline
\end{tabular}


Table.2 Root Colonization (\%) of arbuscular mycorrhizal fungi in sample collected from different locations

\begin{tabular}{|l|c|}
\hline Location & Root colonization(\%) \\
\hline Karanga(KAR) & $55.50\left(48.16^{\mathrm{c}^{*}}\right.$ \\
\hline Upper DeoriGaon (UDG) & $62.40(52.17)^{\mathrm{b}^{* *}}$ \\
\hline NamdeoriGaon (NDG) & $46.50(42.99)^{\mathrm{de}}$ \\
\hline Katoni par (KP) & $64.60(53.48)^{\mathrm{ab}}$ \\
\hline Lahdoigarh (LAH) & $30.80(33.70)^{\mathrm{f}}$ \\
\hline PukhuriporiaGaon (PPG) & $43.50(41.26)^{\mathrm{e}}$ \\
\hline Gibbon Wild Life Sanctuary (GWS) & $66.50(54.63)^{\mathrm{a}}$ \\
\hline Nakachari(NAK) & $48.80(44.31)^{\mathrm{d}}$ \\
\hline Nagajanka (NAG) & $52.70(46.54)^{\mathrm{c}}$ \\
\hline Experimental garden, Department of Horticulture & $54.50(47.58)^{\mathrm{c}}$ \\
\hline (AAU) & 1.73 \\
\hline SEd $( \pm)$ & 3.49 \\
\hline CD $(\mathbf{p}=\mathbf{0 . 0 5})$ & \\
\hline
\end{tabular}

* Data in parentheses are angular transformed value, ** Data followed by same alphabets are statistically at par

Table.3 Spore count of Arbuscular Mycorrhizal Fungi per 100 gm. of soil of different locations

\begin{tabular}{|l|l|}
\hline Location & Spores/ 100 gm of soil \\
\hline Karanaga (KAR) & $152.55^{\mathrm{d}}$ \\
\hline Upper DeoriGaon (UDG) & $168.80^{\mathrm{c}}$ \\
\hline NamdeoriGaon (NDG) & $134.50^{\mathrm{f}}$ \\
\hline Katoni Par (KP) & $176.00^{\mathrm{b}}$ \\
\hline Lahdoigarh (LAH) & $176.00^{\mathrm{b}}$ \\
\hline PukhuriporiaGaon (PPG) & $144.55^{\mathrm{e}}$ \\
\hline Gibbon Wild Life Sanctuary (GWS) & $185.80^{\mathrm{a}}$ \\
\hline Nakachari (NAK) & $155.55^{\mathrm{d}}$ \\
\hline Nagajanka (NAG) & $154.65^{\mathrm{d}}$ \\
\hline Orchard (AAU) & $148.00^{\mathrm{e}}$ \\
\hline S Ed( \pm ) & 2.40 \\
\hline CD (p=0.05) & 4.10 \\
\hline
\end{tabular}

*Data in parentheses are angular transformed value, ** Data followed by same alphabets are statistically at par 


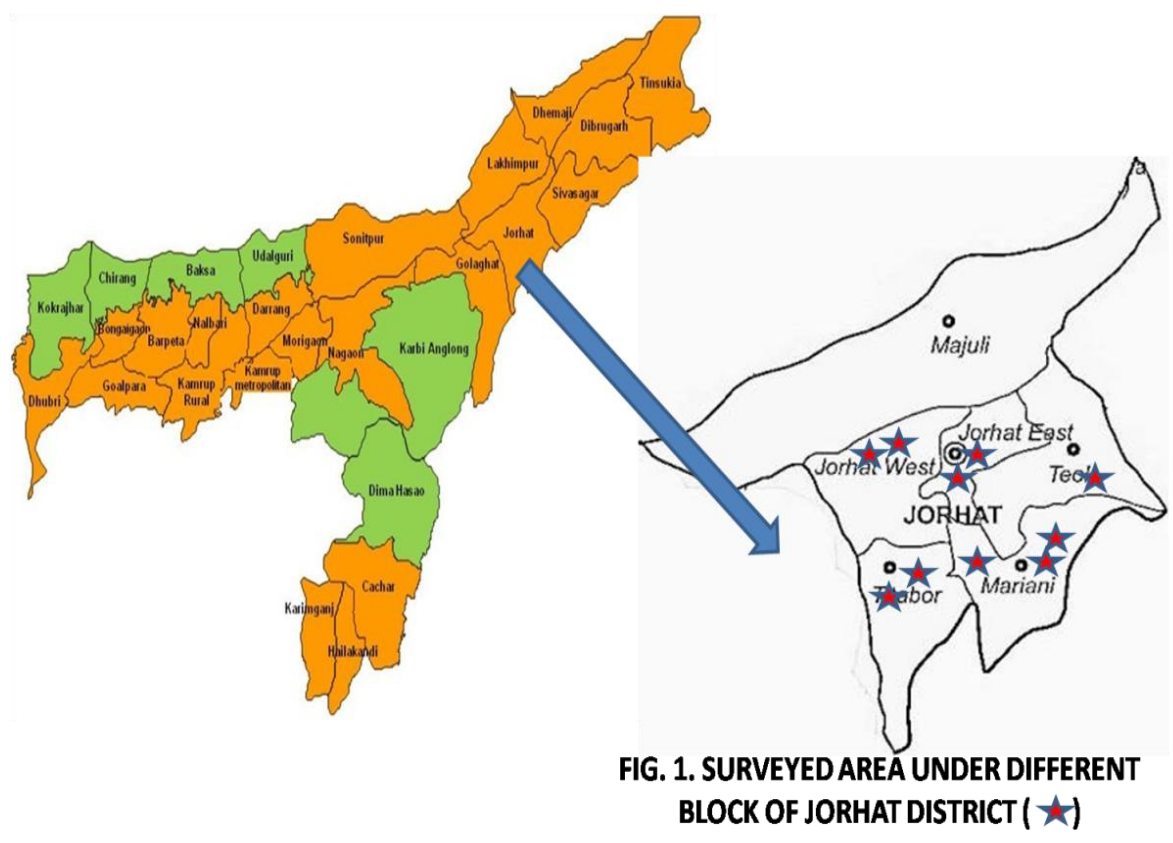

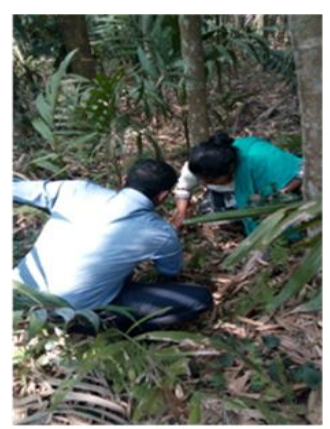

a. Karanga

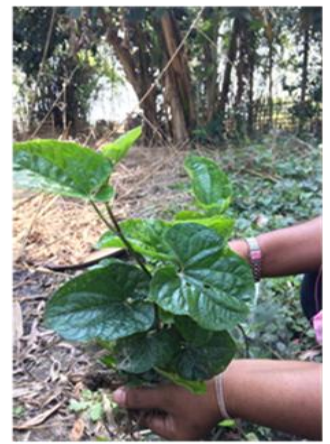

e. Pukhuriporia Gaon

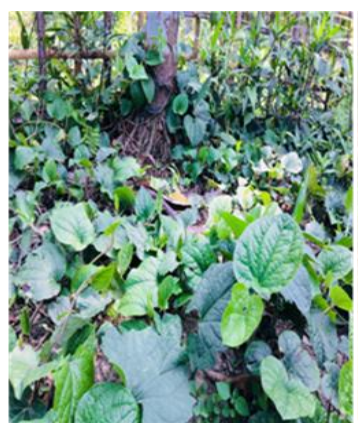

b. Katoni Par

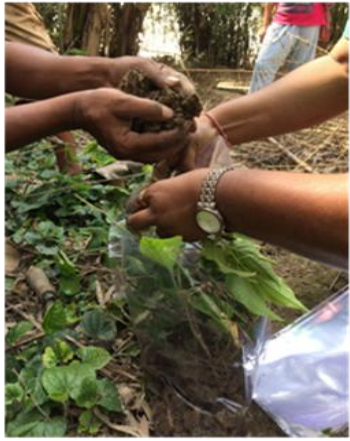

f. Nakachari Gaon

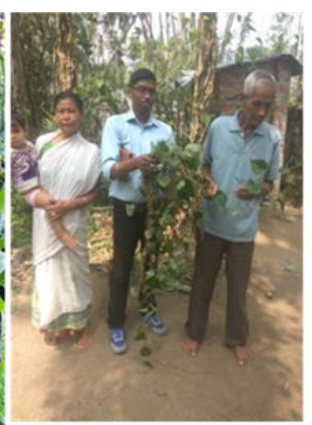

c. Nagajanka

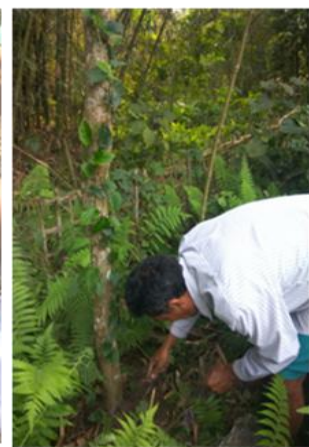

g. Upper Deuri Gaon

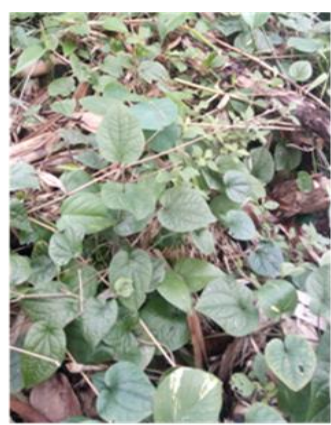

d. Lahdoigarh

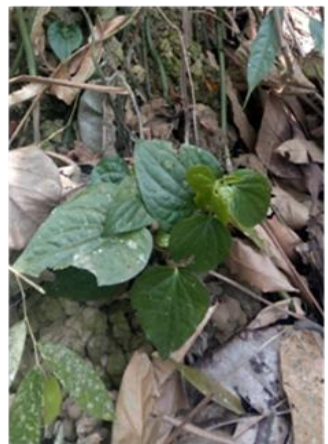

h. Gibbon wild life sanctuary

Plate 1. Survey and collection of sample (root, soil) of Pippali plant from different locations of Jorhat district 

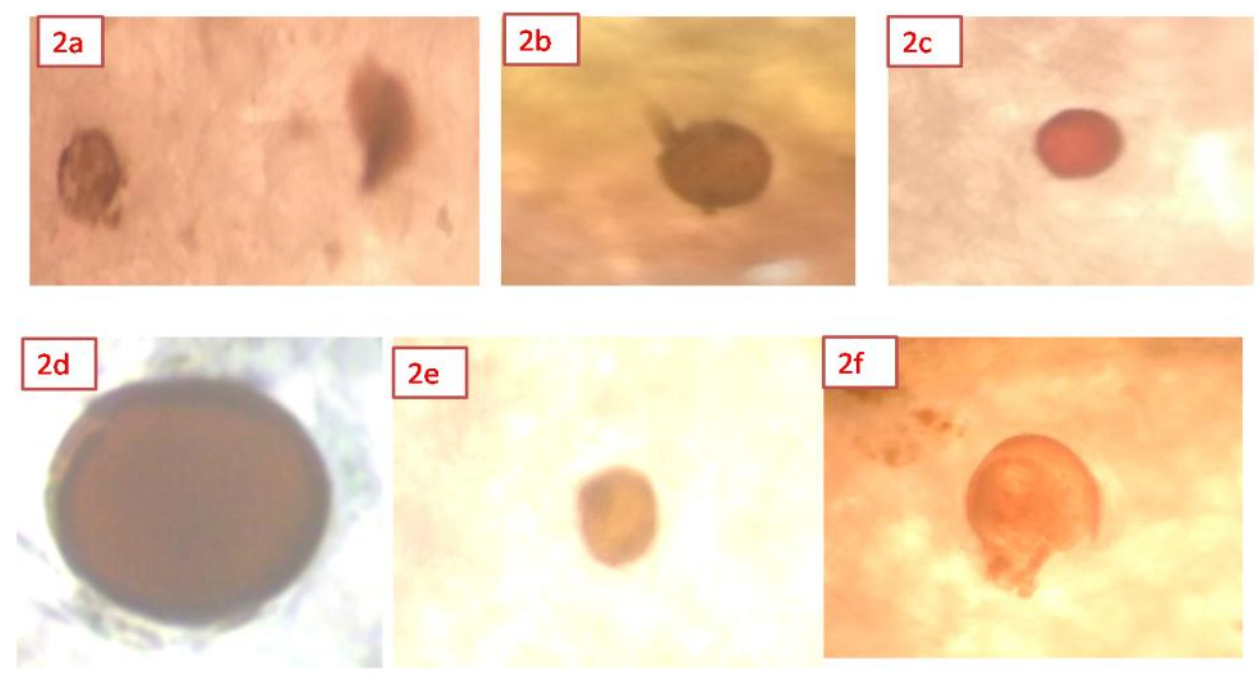

(a-e) Glomus sp

f. Ruptured spores of Glomus sp.

\section{Plate 2(a-f). Spores of Glomus sp. observed in soil sample of different} collection

Extent of root colonization by AMF also varied in different locations of Pippali plant. Colonization was highest in Gibbon wildlife sanctuary followed by Katoniper with whereas lowest in Lahdoigarh area. The variation in root colonization in different location might be related to the soil environmental condition, fertility status, application of chemicals or it may also be attributed to mixed AMF species present in different locations. The Phosphorous level of soil had direct relation with VAM association (Mikola, 1981). The highest AMF population in Gibbon wild life sanctuary might be due to undisturbed condition of soil, which might favor more colonization by AMF fungi for by increasing the fertility status of soil. Similarly, low colonization of Lahdoigarh area of Pippali rhizospheric soil related to high level of available soil phosphorous as the place is highly related to cultivation which made the plant less dependent on AMF fungi for phosphorous nutrition. Changes in soil fertility related to disturbed and undisturbed soil due to amendment with mineral fertilizers can markedly affect the activity of soil mycorrhiza by influencing the level of root infection and spore production. Morita and Konishi (1989) reported that the average percentage of tea root colonization of lightly fertilized soil was two times higher than heavily fertilized fields. The higher root colonization in Gibbon wildlife sanctuary might be due to presence of efficient strain of AMF fungi, which can infect the Pippali root at higher rate.

\section{Acknowledgement}

The author acknowledges the Director of Post Graduate Studies, Professor and Department of Plant Pathology, Director of Research (Agri), Assam Agricultural University, Jorhat, Assam for the constant support and guidance during period of investigation. Due acknowledgement also goes to ICAR-AICRP on MAP and Betelvine, ICAR, New Delhi.

\section{References}

Akiyama K and Hayashi H. (2002) Arbuscular mycorrhizal fungus 
promoted accumulation of two new triterpenoids in cucumber roots. Bioscience, Biotechnology and Biochemistry 66, 762-769

Anonymous (1982) Annual Scientific Report. Tocklai Experimental Station, Jorhat, Assam. pp 55-58.

Baruah, R. (1994). Role of vesicular arbuscular mycorrhiza in legume Rhizobium symbiosis. Ph.D.(Agri.) Thesis, Assam Agricultural University, Jorhat, Assam.

Blaszkowski, J. (1989). Oocystccurrence of the Endogonacea in Poland. Agricultural Ecosystem and Environment 29:45-50.

Chaudhury, A. M. (1998).Spore population and root dynamics and enzyme activities in citrusmycorrhiza.M.sc.(Agri.) Thesis, Assam Agricultural University, Jorhat, Assam.

Das, $\mathrm{R}$ and Barthakur, H.P. (1999).Characterization of VAM fungi occurring in soils of Jorhat district and its surroundings. Journal of Agricultural Science Society North East India.12: 79-83

Gerdamann, J. W. and Nicolson, T. H. (1963). Spores of mycorrhizal endogone species extracted from soil by wet sieving and decanting. Transtellar Brazilian Mycology Society 46:235244.

Gerdemann, J. W. and Trappe, J.M. (1974). The endogonacea in the pacific North West Mycology 5:1-76.

Hazarika, R. L. (1992). Effect of VA mycorrhizal fungi on growth, nutrition and yield of chilli (Capsicum annum L.).M.Sc (Agri.) Thesis, Assam Agricultural University, Jorhat.

Koltai, H. (2010) Arbuscular mycorrhiza symbiosis understress conditions: benefits and costs. In: Seckbach J (ed) Cellularorigin, life in extreme habitats and astrobiology, Volume: Symbiosis and Stress, in press

Larose G, Chenevert R, Moutoglis P, Gagne S, Piche Y and Vierheilig H (2002) Flavonoid levels in roots of Medicago sativa are modulated by the developmental stage of the symbiosis and the root colonizing arbuscular mycorrhizal fungus. Journal of Plant Physiology 159, 1329-1339

Maier W., Peipp H, Schmidt J, Wray V and Strack D (1995) Levels of a terpenoid glycoside (blumenin) and cell wall bound phenolics in some cereal mycorrhizas. Plant Physiology $109,465-470$

Mikola, P. (1981). Mycorrhizas in tropical plants. In: Tropical Mycorrhizal Research Academic Press, London. pp. 79-106.

Morita, J. B. and Konishi, S.(1989). Relationship between VAM infection and soil phosphorous concentration in tea fields.Soil Science and Plant Nutrition 35:139-143.

Phillips, J. M and Haymann, (1970). Improved procedure for clearing roots and staining parasitic and vesicular arbuscular mycorrhizal fungi for rapid assessment of colonization. Trans. Brit. Mycol. Soc., 55:158-160.

Rouphael Y, Cardarelli M, Mattia E. D, Tullio M, Rea E and Colla G. (2010) Enhancement of alkalinity tolerance in two cucumber genotypes inoculated with an arbuscular mycorrhizal biofertilizer containing Glomus intraradices. Biology and Fertility of soils 46, 499-509

Schenck, N. C and Perez, Y.(1988). Manual for the Idenfication of VA Mycorrhizal Fungi. International culture collection of VAM fungi, University of Florida,USA.

Schubler A, Schwarzott D, Walker C (2001) A new fungal phylum, the 
Glomeromycota: Phylogeny and evolution. Mycological Research 105 (12), 1413-1421

Talukdar, N. C. (1993). Occurrence and significance of vesicular arbuscular mycorrhizae in Saskatchewan soils and field crops. Ph.D.Thesis, University of Saskatchewan, Canada.

Trappe, J. M. (1982) Synoptic keys of the genera and the species of Zygomycetous mycorrhizal fungi. Phytopathology72: 1102-1108.

Vierheilig H., H. Gagnon, D. Strack, and W. Maier (2000). Accumulation of cyclohexenone derivatives in barley, wheat and maize roots in response to inoculation with different arbuscular mycorrhizal fungi. Mycorrhiza 9: 291293

Weiss M, Mikolajewski S, Peipp H, Schmidt
U, Schmidt J, Wray V and Strack D (1997)Tissue- specific and development -dependent accumulation of phenylpropanoids in larch mycorrhizas. Plant Physiology 114,15-27

Zarei M, Saleh -Rastin N, Ali Alikhani H and Aliasgharzadeh N (2006) Responses of lentil to co-inoculation with phosphate-solubilizing rhizobial strains and arbuscular mycorrhizal fungi. Journel of Plant Nutrition 29, 1509-1522.

Zhu H. H and Yao Q. (2004) Localized and systematic increase of phenols in tomato roots induced by Glomus versiforme inhibits Ralstonia solanacearum. Journal of Phytopathology 152, 537-542

\section{How to cite this article:}

Deori, M. and Pranab Dutta. 2019. Record of Arbuscular Mycorrhizal Fungi(AMF) in Pippali Plant under the Agro Ecological Conditions of Jorhat District, Assam, India. Int.J.Curr.Microbiol.App.Sci. 8(01): 1011-1019. doi: https://doi.org/10.20546/ijcmas.2019.801.110 